\title{
PENYELENGGARAAN DIKLAT \\ GURU MATA PELAJARAN MADRASAH \\ DI SULAWESI TENGGARA
}

\author{
Asnandar Abubakar*
}

Balai Peneitian dan Pengembangan Agama Makassar JI. AP.Pettarani No. 72 Makassar Email: asnandar2.aja@gmail.com

\begin{tabular}{|c|c|}
\hline INFO ARTIKEL & ABSTRAK \\
\hline & $\begin{array}{l}\text { Penelitian ini bertujuan untuk mengetahui tanggapan guru mata pelajaran } \\
\text { madrasah terhadap proses penyelenggaraan diklat dilihat dari aspek materi, } \\
\text { widyaiswara, dan metode diklat. Penelitian ini adalah gabungan penelitian } \\
\text { kualitatif dan kuantitatif, yang dilaksanakan di Provinsi Sulawesi Tenggara } \\
\text { dengan fokus penelitian pada guru-guru yang telah mengikuti diklat guru mata } \\
\text { pelajaran. Teknik pengumpulan data yang dilakukan adalah melalui } \\
\text { angket/kuisioner dan wawacara. Angket digunakan untuk mengumpulkan data } \\
\text { kuantitatif dan wawancara digunakan untuk mengumpulkan data kualitatif. Hasil } \\
\text { penelitian menunjukkan tanggapan guru-guru terhadap penyelenggaraan diklat } \\
\text { terkait materi cenderung baik meskipun terdapat tanggapan bahwa isi materi } \\
\text { diharapkan ada kebaruan yang berhubungan dengan peningkatan kualitas } \\
\text { pembelajaran. Tanggapan guru terkait widyaiswara juga baik, widyaiswara } \\
\text { mampu memberikan pembelajaran secara baik dan efektif, guru mengharapkan }\end{array}$ \\
\hline $\begin{array}{r}\text { Kata Kunci: } \\
\text { Diklat Guru, Guru } \\
\text { Mata Pelajaran, } \\
\text { Widyaiswara }\end{array}$ & $\begin{array}{l}\text { ada inovasi-inovasi pembelajaran yang esensial. Tanggapan guru terkait metode } \\
\text { diklat juga baik, metode diklat harus dibarengi dengan inovasi-inovasi agara } \\
\text { pembelajaran dapat berjalan secara efektif dan efesien, salah metode yang } \\
\text { digunakan pada pembelajaran adalah metode kolaborasi, karena } \\
\text { mengikutsertakan partisipasi semua peserta diklat. }\end{array}$ \\
\hline
\end{tabular}

\section{ABSTRACT}

This study aims to determine the response of madrasah subject teachers to the process of conducting education and training viewed from the aspect of the material, lecture, and training methods. This research is a combination of qualitative and quantitative research, which was carried out in Southeast Sulawesi Province with a focus of research on teachers who have attended subject teacher training. Data collection techniques used were through questionnaires/questionnaires and interviews. The questionnaire was used to collect quantitative data and interviews were used to collect qualitative data. The results showed that teachers' responses to the implementation of education and training related to the material tended to be good although there was a response that the content of the material was expected to be novelty related to improving the quality of learning. Teacher responses related to widyaiswara are also good, widyaiswara can provide good and effective learning, teachers expect

Keywords:

Teacher Training,

Subject Teachers,

Widyaiswara there are essential learning innovations. Teacher responses related to the training method are also good, the training method must be accompanied by innovations so that learning can run effectively and efficiently, one of the methods used in learning is a collaborative method, because it involves the participation of all training participants

\section{PENDAHULUAN}

Pendidikan dan pelatihan (diklat) bagi pegawai baik aparatur sipil negara (ASN) maupun non ASN dewasa ini, sudah menjadi kebutuhan utama (main needs) sebagai modal meningkatkan kompetensi, kinerja, dan kualitas kerja. Diklat bagi pegawai (sumber daya manusia) merupakan kegiatan strategis dalam menata 
kompetensi menuju profesional kerja. Pegawai yang profesional akan memberikan kinerja yang excellent dalam menunjang reformasi tata kelola pemerintahan yang baik (good governance).

Guru sebagai salah satu ASN merupakan penopang penyelenggaraan pendidikan juga dituntut mengembangkan dan menjaga profesionalisme kerja. Pengembangan dan peningkatan profesionalisme guru dapat dilakukan dengan upgrading status pendidikan dan pengembangan sumber daya manusia (SDM) dengan pendidikan dan latihan (diklat). Diklat guru merupakan salah satu sarana meningkatkan keprofesionalan dalam bekerja. (Wardoyo and Supriyoko, 2018:108).

Pengembangan sumber daya manusia pendidik dan tenaga kependidikan yang dilakukan oleh penyelenggara diklat (lembaga pemerintah dan non pemerintah) ditujukan untuk meningkatkan pengetahuan (knowledge), kemampuan (ability), dan keterampilan (skill) sesuai dengan tuntutan tugas dan kewajiban serta untuk mendukung proses belajar mengajar di sekolah. Pada lembaga pemerintah, selain meningkatkan kualitas pendidik, diklat juga untuk dilakukan sebagai upaya menuju pemerintahan good governance.

Dalam rangka menuju good governance, maka profeionalitas kerja dan kinerja harus ditingkatkan dan ditata sedemikian rupa sesuai dengan tujuan yang ingin dicapai. Olehnya dalam penyelenggaraan diklat, bukan saja ASN yang mengikuti diklat yang diharapkan kinerjanya meningkat, tetapi juga pelaksana atau penyelenggara diklat yang diharapkan memberikan kinerja dan layanan yang prima sesuai dengan tatanan dan pedoman kediklatan yang baik.

Kinerja pegawai pada pekerjaan yang sedang dijalaninya dapat ditingkatkan melalui proses aktivitas sebuah pelatihan telan yang didesain (Philip, 1991). Sementara itu, pendapat lain dikemukakan oleh Gomes (2003) yang menyatakan pelatihan juga dapat dikatakan pengembangan (development) yang merupakan kesempatan belajar (learning opportunities) yang ditata sedemikian rupa untuk membantu pengembangan para pekerja. (Widianto, 2018:41).

Sumber daya manusia pada lembaga pendidikan merupakan faktor utama dalam proses pelaksanaan pembelajaran, meskipun terkadang tidak terlalu siap menghadapi kecepatan ilmu pengetahuan dan teknologi. Seperti yang disebutkan Maisyaroh (dalam Widianto, 2018) pada sumber daya manusia di lembaga pendidikan merupakan faktor yang berperan dalam mewujudkan pendidikan yang bermutu (Widianto, 2018:41). Lembaga pendidikan seperti sekolah, perlu mengadakan program pelatihan bagi guru untuk kemajuan dan kepentingan sekolah (Rahayu, 2016:134).

Salah satu rencana strategis (RENSTRA) Badan Litbang dan Diklat Kementerian Agama adalah Peningkatan kualitas sistem penyelenggaraan diklat. Penetapan rencana strategi diharapkan mampu meningkatkan kinerja penyelenggaran diklat menuju reformasi bikrokrasi, sehingga pada pelaksanaan diklat akan menghasilkan ASN yang memiliki kecakapan dan profesionalitas yang tinggi dalam bekerja, serta memiliki moral, spiritual, dan intelektual yang baik. Sedaramyanti (dalam Padilah, 2016) menjelaskan bahwa dengan pendidikan dan pelatihan memberikan proses transformasi kualitas sumber daya manusia aparatur negara pada empat dimensi (dimensi spiritual, intelektual, mental, dan fisik) kearah yang lebih baik.

Dalam mencapai tujuan penyelenggaraan diklat yang baik maka harus ditetapkan program dan tata kelola yang baik. Pengelolaan yang baik mampu mencapai tujuan penyelenggaraan diklat secara maksimal. Daryanto (dalam Padilah 2016) mengemukakan prosedur pengelolaan pelatihan, yaitu: (1) Adanya Identifikasi dan Analisis Kebutuhan Pelatihan; (2) Menetapkan pengujian dan Analisis Jabatan; (3) mengklasifikasi dan 
menentukan peserta pelatihan; (4) merumuskan tujuan pelatihan; (5) mendesainan kurikulum dan silabus pelatihan; (6) merencanakn program pelatihan; (7) menyusun dan mengembangkan kerangka acuan; (8) melaksanakan program pelatihan; (9) mengevaluasi program pelatihan; dan (10) adanya tindak lanjut pelatihan.

Program dan rancang bangun diklat sangat diperlukan sebelum memulai pelaksanaan. Rancang bangun program diklat dapat dilakukan dengan beberapa langkah, yaitu; mengetahui secara sistematis tahapan kegiatan diklat; mengetahui aspek-aspek dan fokus diklat; mengetahui model diklat yang di gunakan; menyiapkan bahan yang di gunakan. Faedah dari rancang bangun, yaitu antara lain; sebagai pedoman/ acuan dalam pelaksanaan diklat; sebagai persiapan bahan-bahan, metode yang di gunakan model rancang bangun dalam diklat (Anwar, n.d:5).

Pada analisis lebih dalam, maka analisis kebutuhan diklat memiliki beberapa harapan lain untuk dicapai, yakni: a. Menegaskan bahwa diklat dapat meningkatkan produktivitas pada peserta diklat dan menjadi salah satu solusi untuk itu. b. Menegaskan bahwa diklat dilaksanakan untuk peserta yang memang membutuhkan. c. Menegaskan apa yang dibagi pada pelaksanaan diklat sesuai dengan kompetensi peserta yang mengikuti. d. Mengetahui jenis diklat yang sesuai dengan kompetensi peserta. e. Menegaskan bahwa diklat dapat mengatasi masalah yang berkenaan dengan tidak efektifnya produktivitas peserta dalam perusahaan (Sugiarto, Sunarto, and Maulana, 2016:2) Beberapa hasil penelitian menunjukkan pengaruh yang signifikan dan manfaat dari penyelenggaraan diklat yang diikuti oleh guru sekolah. Seperti penelitian yang dilakukan oleh Wardoyo and Supriyoko (2018) terhadap guru Sekolah Menengah Kejuruan Negeri se-Kabupaten Wonosobo, menyimpulkan bahwa terdapat pengaruh signifikan pengalaman diklat, motivasi kerja dan masa kerja terhadap profesionalisme guru Sekolah Menengah Kejuruan di Kabupaten Wonosobo. Dan juga ditemukan pengaruh signifikan pengalaman diklat, terhadap profesionalisme guru Sekolah Menengah Kejuruan di Kabupaten Wonosobo (Wardoyo and Supriyoko, 2018:114).

Begitu juga penelitian yang dilakukan oleh Yulian dan Akbar (Yulian and Akbar, 2016) tentang pengaruh dari perencanaan diklat terhadap efektivitas pelaksanaan diklat di UPTD Balai Latihan Kerja Dinas Sosial Tenaga Kerja dan Transmigrasi Kabupaten Garut menunjukkan berkolerasi yang baik artinya tata kelola dan perencaan yang baik akan menghasilkan proses penyelenggaraan diklah yang maksimal. Penelitian yang dilakukan oleh Hidayati and Khafid (2015) menyimpulkan bahwa terdapat pengaruh antara motivasi kerja, kompensasi, dan pengalaman diklat terhadap kinerja guru ekonomi/akuntansi di SMA Negeri se Kabupaten Tegal baik secara parsial maupun simultan (Hidayati and Khafid 2015).

\section{Rumusan Masalah}

Rumusan masalah penelitian ini adalah bagaimana tanggapan guru mata pelajaran madrasah terhadap proses penyelenggaraan diklat dilihat dari aspek materi, widyaiswara, dan metode diklat?

\section{Tujuan dan Kegunaan Penelitian}

Tujuan penelitian ini adalah untuk mengetahui tanggapan guru mata pelajaran madrasah terhadap proses penyelenggaraan diklat dilihat dari aspek materi, widyaiswara, dan metode diklat. Kegunaan penelitian diharapkan memberikan informasi-informasi efektifitas penyelenggaraan diklat terkait dengan materi, widyaiswara, dan metode diklat. Bahan masukan bagi penyelenggara diklat untuk memberikan pelayanan diklat baik materi maupun metode yang lebih konstruktif. Memberikan informasi akan urgensi diklat bagi guru-guru madrasah terhadap peningkatan kompetensi. 


\section{Batasan Operasional Penelitian}

Pada penelitian ini, tanggapan guru mata pelajaran madrasah terhadap proses penyelenggaraan diklat adalah analisis pernyataan pada kuisioner yang diisi oleh guru mata pelajaran berdasarkan variabel materi, variabel widyaiswara, dan variabel metode diklat. Variabel-variabel tersebut berserta masing-masing indikatornya tersebut tidak dianalisis secara regresi dan juga tidak dikolerasikan

\section{Kajian Teori}

Pendidikan dan latihan (diklat) merupakan suatu rangkaian yang sistematik dan terorganisasi dari kegiatan-kegiatan yang dirancang untuk meningkatkan pengetahuan, keterampilan, dan pemahaman dan/atau motivasi yang berhubungan dengan kerja seorang individu (Wardoyo and Supriyoko, 2018:109).

Pada Peraturan Pemerintah Nomor 101 Tahun 2000 tentang Pendidikan dan Pelatihan Jabatan Pegawai Negeri Sipil pasal 1 ayat (1) disebutkan bahwa Pendidikan dan Pelatihan Jabatan Pegawai Negeri Sipil yang selanjutnya disebut Diklat adalah proses penyelenggaraan belajar mengajar dalam rangka meningkatkan kemampuan Pegawai Negeri Sipil.

Lebih lanjut dijelaskan pada Peraturan Menteri Agama Republik Indonesia Nomor 75 Tahun 2015 tentang Penyelenggaraan Pendidikan dan Pelatihan Pegawai pada Kementerian Agama Pasal 1 ayat (1) pendidikan dan pelatihan (Diklat) adalah penyelenggaraan pembelajaran dan pelatihan dalam rangka mengembangkan kompetensi pegawai sesuai persyaratan jabatan masing-masing pada Kementerian Agama yang dilaksanakan paling sedikit 40 (empat puluh) jam pelajaran, dengan durasi tiap jam pelajaran 45 (empat puluh lima) menit. Pada pasal 8 ayat (1) disebutkan bahwa Diklat Teknis merupakan diklat yang dilaksanakan untuk memenuhi standar kompetensi teknis pegawai sesuai dengan kebutuhan pelaksanaan tugas masingmasing.

Demikian juga pada Peraturan Menteri Agama Republik Indonesia Nomor 43 tahun 2016 tentang Sistem Informasi Manajemen Pendidikan dan Pelatihan pada Kementerian Agama, pasal 1 ayat (2) juga disebutkan bahwa pendidikaan dan pelatihan yang selanjutnya disebut diklat adalah penyelenggaraan pembelajaran dan pelatihan dalam rangka mengembangkan kompetensi pegawai sesuai persyaratan jabatan masing-masing pada Kementerian Agama".

Cartwright . (dalam Widianto, 2018:41) menyatakan diklat bertujuan agar pekerja atau staf dapat melaksanakan pekerjaan yang dilakukan sekarang dengan lebih baik, mampumelaksanakan pekerjaan pada masa yang akan datang, mengembangkan dan menjadikan staf lebih nyaman untuk berkembang bersama lembaga

Diklat merupakan bagian integral dari pengembangan sumber daya manusia dalam rangka mempersiapkan tenaga pendidik yang trampil, disiplin dan produktif (Syaifulloh and Pranoto, 2017:19). Menurut Vaithzal (dalam Nurmasari, 2016:2) Pendidikan dan pelatihan sangat penting bagi pegawai baru maupun pegawai yang sudah lama, karena pelatihan merupakan suatu kegiatan untuk meningkatkan kinerja saat ini dan kinerja dimasa mendatang.

Hasibuan (dalam Nurmasari, 2016:2) bahwa pendidikan dan pelatihan bertujuan untuk meningkatkan kemampuan teknis, teoritis, konseptual dan moral pegawai supaya prestasi kerjanya baik dan mencapai hasil yang optimal dalam menjalankan tugas dan fungsinya. Sedangkan Handoko (2010) (dalam Widianto, 2018:42) menyatakan bahwa program pelatihan dan pengembangan dirancang untuk meningkatkan prestasi kerja, mengurangi absensi dan perputaran, serta memperbaiki kepuasan kerja.

Daryanto dan Bintoro (2014) (dalam Siregar, 2018:155) mengatakan bahwa 
kegiatan-kegiatan pendidikan dan pelatihan (diklat) dilaksanakan sebagai upaya yang disebabkan karena kekurangmampuan manusiawi (humanistic skill), kurangnya kemampuan teknis (technical skill), atau kurangnya kemampuan manajerial (manajerial skill). Dengan pemahaman akan pentingnya meningkatkan kualitas kemampuan yang menyangkut kemampuan kerja, berpikir dan keterampilan, maka pendidikan dan pelatihan mempunyai peran yang sangat diperlukan sebagaimana yang dikemukakan oleh Notoatmodjo (2010) (dalam Siregar, 2018:155) bahwa pendidikan dan pelatihan adalah merupakan upaya untuk mengembangkan sumber daya aparatur, terutama untuk peningkatan profesionalime yang berkaitan dengan, keterampilan administrasi dan keterampilan manajemen (kepemimpinan).

Beberapa ahli/pakar memisahkan konsep pendidikan dan konsep pelatihan dalam memaknai diklat. Seperti Siagian (1999) (dalam Nurmasari, 2016:5) mengemukanan bahwa pendidikan adalah keseluruhan proses, teknik dan metode belajar mengajar dalam rangka mengalihkan suatu pengetahuan dari seseorang kepada orang lain sesuai dengan standar yang telah ditetapkan sebelumnya. Sedangkan pelatihan adalah proses belajar mengajar, dengan mempergunakan teknik dan metode tertentu. Suwanto dan Priansa (2012) (dalam Siregar, 2018:155) menjelaskan bahwa pendidikan merupakan suatu kegiatan untuk meningkatkan pengetahuan umum seseorang termasuk didalamnya peningkatan penguasaan teori dan keterampilan memutuskan terhadap persoalan-persoalan yang menyangkut kegiatan mencapai tujuan. Pelatihan adalah suatu kegiatan untuk memperbaiki kemampuan kerja seseorang, membantu memahami suatu pengetahuan praktis dan penerapannya guna meningkatkan keterampilan, kecakapan dan sikap yang diperlukan organisasi dalam usaha mencapai tujuannya.

Diklat memiliki tujuan umum sebagai berikut: a. Memperkuat kemampuan peserta sehingga tanggung jawab dan pekerjaan dapat dilaksanakan secara lebih akurat dan efektif. b. Memperkuat ilmu pengetahuan sehingga tanggung jawab dan pekerjaan dapat dilaksanakan dengan lebih rasional. c. Memperbaiki sikap sehingga menghasilkan inisiatif dalam bekerja dalam tim (Sugiarto, Sunarto, and Maulana, 2016:2)

Pelaksanaan diklat, selain bermanfaat bagi pegawai sebagai upgrading kompetensi dan peningkatan kinerja juga sangat bermanfaat bagi lembaga atau organisasi. Sondang P. Siagian (1999) (dalam Sulistyo, Minarsih, and Warso, 2016) mengemukakan manfaat pendidikan dan pelatihan bagi organisasi, diantaranya: 1. Peningkatan produktivitas organisasi secara keseluruhan. 2. Terwujudnya hubungan yang serasi antara atasan dan bawahan.3. Terjadi proses pengambilan keputusan yang lebih cepat dan tepat4. Timbul dorongan pada diri pekerja untuk terus meningkatkan kemampuan kerjanya. 5. Peningkatan kemampuan pegawai untuk mengatasi stress, frustasi dan konflik. 6 . Meningkatkan kepuasan kerja. 7. Semakin besar pengakuan atas kemampuan seorang. 8. Mengurangi ketakutan menghadapi tugas-tugas baru dimasa depan.

Menurut Atmodiwirio (2002) (dalam Nuraeni and Riyanto, 2017:25) menyatakan bahwa pendidikan dan pelatihan tersebut sangat diperlukan oleh suatu organisasi, karena memiliki berbagai manfaat diantaranya adalah: a. Bermanfaat untuk memenuhi kebutuhan organisasi, organisasi membutuhkan orang-orang yang mampu melaksanakan tugas yang telah ditetapkan sesuai dengan pengertian jabatan $b$. Bermanfaat untuk memenuhi kebutuhan pribadi, kebutuhan pribadi merupakan bagian bagian yang tidak terpisahkan dari organisasi c. Bermanfaat untuk memenuhi kebutuhan investasi sumber daya manusia, diklat tak ubahnya sebagai pendidikan formal membutuhkan pengadaan biaya yang tidak sedikit. d. Bermanfaat bagi setiap pejabat atau jenjang kepangkatan.

Berhasil tidaknya proses penyelenggaraan diklat, juga tidak lepas 
dari peran tenaga instruktur atau widyaiswara. Kompetensi dan kualitas widyaiswara sangat menentukan ketercapaian sasaran dan tujuan diklat. Peraturan Kepala Lembaga Administrasi Negara Nomor 5 Tahun 2008 tentang Standar kompetensi widyaiswara pada pasal 5 menyebutkan bahwa standar kompetensi widyaiswara terdiri dari 4 kompetensi, yaitu; kompetensi pengelolaan pembelajaran, kompetensi kepribadian, kompetensi sosial, dan kompetensi substantif.

Pada Peraturan Menteri Agama Republik Indonesia Nomor 75 Tahun 2015 pasal 1 ayat (19) menyebutkan bahwa Widyaiswara adalah ASN yang diangkat sebagai pejabat fungsional oleh pejabat yang berwenang dengan tugas, tanggung jawab, wewenang untuk mendidik, mengajar dan/atau melatih serta melaksanakan pengembangan kediklatan.

Kualitas seorang istruktur/pelatih sangat mempengaruhi kualitas sasaran peserta didik. Oleh karena itu, seorang istruktur/pelatih harus memiliki kemampuan berikut: (1) penguasaan materi yang akan diajarkan; (2) kemampuan menyusun materi ajar; (3) kemampuan memilih dan mengembangkan metode pembelajaran; (4) kemampuan menggunakan media dan sumber-sumber belajar; (5) kemampuan mengelola kelas; dan (6) kemampuan ber-komunikasi dan membina hubungan dengan peserta diklat (Siregar, 2018:158).

Dalam pengelolaan kelas dan proses pembelajaran, widyaiswara harus cermat dalam memilih metode diklat yang digunakan. Pada penjelasan atas Peraturan Pemerintah Nomor 101 Tahun 2000 pasal 18 menyebutkan bahwa metode Diklat adalah metode bagi orang dewasa dengan memperhatikan: (1) sesuai dengan kebutuhan praktis dan pengembangan diri peserta; (2) bersifat interaktif antara peserta dengan widyaiswara dan antar peserta; (3) berlangsung dalam suasana belajar yang bebas, dinamis, dan fleksibel.

\section{METODE PENELITIAN}

Jenis penelitian ini adalah mix method (penelitian kualitatif dipadukan dengan penelitian kuantitatif). fokus penelitian pada guru-guru mata pelajaran madrasah di Wilayah Kementerian Agama Provinsi Sulawesi Tenggara yang telah mengikuti diklat guru mata pelajaran yang diselenggarakan oleh Balai Pendidikan Dan Pelatihan Keagamaan Kementerian Agama Republik Indonesia.

Teknik pengumpulan data adalah melalui angket/kuisioner untuk mengumpulkan data kuantitatif dan melalui wawacara untuk mengumpulkan data kualitatif sebagai penguatan data kuantitatif. Sampel penelitian adalah purposive sumpling, yaitu memilih langsung guru madrsah yang telah mengikuti diklat guru mata pelajaran. Pemilihan sampel mempertimbangkan waktu, jarak tempuh, dan biaya. Pada penelitian ini, guru diminta tanggapannya melalui kuisioner terhadap penyelenggaraan diklat guru mata pelajaran.

Instrumen penelitian dengan sub variabel; materi diklat, widyaiswara, dan metode pelaksanaan diklat diturunkan dari Pada Peraturan Pemerintah Nomor 101 Tahun 2000 tentang Pendidikan dan Pelatihan Jabatan Pegawai Negeri Sipil, Peraturan Menteri Agama Republik Indonesia Nomor 75 Tahun 2015 tentang Penyelenggaraan Pendidikan dan Pelatihan Pegawai Kementerian Agama, Peraturan Menteri Agama Republik Indonesia Nomor 43 tahun 2016 tentang Sistem Informasi Manajemen Pendidikan dan Pelatihan pada Kementerian Agama, dan Peraturan Kepala Lembaga Administrasi Negara Nomor 5 Tahun 2008 tentang Standar kompetensi widyaiswara.

Analisi data dilakukan dengan mengukur hasil tabulasi variabel materi diklat, widyaiswara, dan metode diklat dengan menggunakan skala linkert, kemudian diinterpretasi berdasarkan pernyataan Sangat Setuju (ST,5), Setuju $(\mathrm{S}, 4)$, Ragu-Ragu (R,3), Tidak Setuju 
(TS,2), dan Sangat Tidak Setuju (STS,1). Hasil akhir adalah nilai rata-rata berdasarkan distribisi frekuensi dengan menggunakan aplikasi SPSS versi 16.0. nilai rata-rata selanjutnya diinterpretasi dengan kategori Sangat Tidak Baik, Tidak Baik, Sedang, Baik, dan Sangat Baik.

Skala pengukuran ditentukan dari nilai tertinggi skala pengukuran (5) dikurangi nilai terendah (1) dibagi banyaknya kategori (5), seperti rumus berikut:

$$
\begin{gathered}
I=\frac{N \max -N \min }{K} \\
I=\frac{5-1}{5}=0.8
\end{gathered}
$$
berikut:

Interval kategori ditentukan sebagai

\begin{tabular}{|ccc|}
\hline No. & Interval & Interpretasi jawaban \\
\hline 1 & $1.00-1.80$ & Sangat tidak baik \\
2 & $1.81-2.60$ & Tidak baik \\
3 & $2.61-3.40$ & Sedang \\
4 & $3.41-4.20$ & Baik \\
5 & $4.21-5.00$ & Sangat baik \\
\hline
\end{tabular}

\section{HASIL DAN PEMBAHASAN}

\section{Gambaran Umum Lokasi Penelitian}

Provinsi Sulawesi Tenggara terletak di bagian Selatan Garis Khatulistiwa, secara geografis memanjang dari Utara ke Selatan di antara $02^{\circ} 45^{\prime}-06^{\circ} 15^{\prime}$ Lintang Selatan dan membentang dari Barat ke Timur di antara $120^{\circ} 45^{\prime}-124^{\circ} 45^{\prime}$ Bujur Timur. Luas wilayah Sulawesi Tenggara $38.067,7 \mathrm{~km} 2$. Provinsi Sulawesi Tenggara di sebelah Utara berbatasan dengan Provinsi Sulawesi Selatan dan Provinsi Sulawesi Tengah, sebelah Selatan berbatasan dengan Provinsi NTT di Laut Flores, sebelah Timur berbatasan dengan Provinsi Maluku di Laut Banda dan sebelah Barat berbatasan dengan Provinsi Sulawesi Selatan di Teluk Bone.

Sulawesi Tenggara terdiri dari 15 kabupaten, 2 kota, 222 kecamatan dan $1.914 \mathrm{desa} /$ kelurahan. Luas masing-masing kabupaten/kota, yaitu: Buton (1.212,99 km2), Muna (1.922,16 km2), Konawe $(4.435,28 \mathrm{~km} 2)$, Kolaka (3.283,59 km2), Konawe Selatan $(5.779,47 \mathrm{~km} 2)$, Bombana (3.001 km2), Wakatobi (559,54 km2), Kolaka Utara $(3.391,67 \mathrm{~km} 2)$, Buton Utara $(1.864,91 \mathrm{~km} 2)$, Konawe Utara $(5.101,76$ $\mathrm{km} 2)$, Kolaka Timur (3.634,74 km2), Konawe Kepulauan $(867,58$ km2), Muna Barat (1.022,89 km2), Buton Tengah (958,31 km2), Buton Selatan (509,92 km2), Kota Kendari $(300,89 \mathrm{~km} 2)$ dan Kota Baubau (221 km2).

Jumlah Madrasah Tsanawiyah dan

\begin{tabular}{|c|c|c|c|c|c|}
\hline \multirow{3}{*}{ No } & \multirow{3}{*}{$\begin{array}{c}\text { Kabupaten/ } \\
\text { Kota }\end{array}$} & \multicolumn{4}{|c|}{ Madrasah } \\
\hline & & \multicolumn{2}{|c|}{ MTs } & \multicolumn{2}{|c|}{ MA } \\
\hline & & Negeri & Swasta & Negeri & Swasta \\
\hline 1 & Kolaka & 2 & 19 & 2 & 9 \\
\hline 2 & Konawe & 3 & 17 & 1 & 11 \\
\hline 3 & Muna & 5 & 13 & 1 & 10 \\
\hline 4 & Buton & 4 & 3 & 1 & 3 \\
\hline 5 & Konawe Selatan & 4 & 24 & 2 & 15 \\
\hline 6 & Bombana & 5 & 13 & 2 & 9 \\
\hline 7 & Wakatobi & 4 & 7 & 2 & 4 \\
\hline 8 & Kolaka Utara & 3 & 13 & 1 & 9 \\
\hline 9 & Buton Utara & 0 & 6 & 0 & 5 \\
\hline 10 & Konawe Utara & 1 & 2 & 0 & 2 \\
\hline 11 & Kolaka Timur & 1 & 14 & 0 & 6 \\
\hline 12 & $\begin{array}{l}\text { Konawe } \\
\text { Kepulauan }\end{array}$ & 2 & 1 & 0 & 1 \\
\hline 13 & Kendari & 2 & 13 & 1 & 6 \\
\hline 14 & Bau-Bau & 1 & 8 & 1 & 5 \\
\hline 15 & Buton Selatan & 4 & 5 & 1 & 3 \\
\hline 16 & Buton Tengah & 4 & 10 & 1 & 6 \\
\hline 17 & Muna Barat & 0 & 6 & 0 & 4 \\
\hline & Jumlah & 45 & 174 & 16 & 108 \\
\hline \multicolumn{2}{|c|}{ Jumlah Keseluruhan } & \multicolumn{2}{|c|}{219} & \multicolumn{2}{|c|}{124} \\
\hline
\end{tabular}
Madrasah Aliyah Sulawesi Tenggara 2017

Sumber: Data Kanwil Kemenag Provinsi Sultra, 2018. 
Educandum: Volume 6 Nomor 2 Juni 2020

\begin{tabular}{|c|l|c|c|c|c|}
\hline \multirow{2}{*}{ No } & \multirow{2}{*}{$\begin{array}{c}\text { Kabupaten/ } \\
\text { Kota }\end{array}$} & \multicolumn{4}{|c|}{ Madrasah } \\
\cline { 3 - 6 } & & \multicolumn{2}{|c|}{ MTs } & \multicolumn{2}{|c|}{ MA } \\
\cline { 3 - 6 } & & $\begin{array}{c}\text { NON } \\
\text { PNS }\end{array}$ & PNS & $\begin{array}{c}\text { NON } \\
\text { PNS }\end{array}$ \\
\hline $\mathbf{1}$ & Kolaka & 74 & 239 & 40 & 121 \\
\hline $\mathbf{2}$ & Konawe & 85 & 189 & 40 & 101 \\
\hline $\mathbf{3}$ & Muna & 83 & 171 & 40 & 91 \\
\hline $\mathbf{4}$ & Buton & 38 & 77 & 15 & 56 \\
\hline $\mathbf{5}$ & Konawe Selatan & 56 & 216 & 42 & 171 \\
\hline $\mathbf{6}$ & Bombana & 64 & 177 & 16 & 119 \\
\hline $\mathbf{7}$ & Wakatobi & 31 & 125 & 18 & 80 \\
\hline $\mathbf{8}$ & Kolaka Utara & 41 & 152 & 9 & 81 \\
\hline $\mathbf{9}$ & Buton Utara & 4 & 60 & 1 & 52 \\
\hline $\mathbf{1 0}$ & Konawe Utara & 12 & 34 & 1 & 25 \\
\hline $\mathbf{1 1}$ & Kolaka Timur & 31 & 138 & 7 & 46 \\
\hline $\mathbf{1 2}$ & $\begin{array}{l}\text { Konawe } \\
\text { Kepulauan }\end{array}$ & 15 & 26 & 1 & 8 \\
\hline $\mathbf{1 3}$ & Kendari & 109 & 130 & 62 & 71 \\
\hline $\mathbf{1 4}$ & Bau-Bau & 42 & 103 & 47 & 77 \\
\hline $\mathbf{1 5}$ & Buton Selatan & 29 & 100 & 10 & 45 \\
\hline $\mathbf{1 6}$ & Buton Tengah & 52 & 160 & 27 & 91 \\
\hline $\mathbf{1 7}$ & Muna Barat & 10 & 61 & 6 & 45 \\
\hline
\end{tabular}

\begin{tabular}{|c|c|c|c|c|}
\hline Jumlah & $\mathbf{7 7 6}$ & $\mathbf{2 1 5 8}$ & $\mathbf{3 8 2}$ & $\mathbf{1 2 8 0}$ \\
\hline Jumlah Keseluruhan & $\mathbf{2 9 3 4}$ & $\mathbf{1 6 6 2}$ \\
\hline $\begin{array}{l}\text { Sumber: Data Kanwil Kemenag Provinsi } \\
\text { Sultra, 2018 }\end{array}$
\end{tabular}

\section{Identitas Responden}

Responden atau sampel penelitian adalah guru-guru madrasah aliyah dan madrasah tsanawiyah pada 8 (delapan) kabupaten/kota di wilayah Provinsi Sulawesi Tenggara. Jumlah responden guru sebanyak 13 (tigabelas) orang. Dari 13 responden guru tersebut, 8 guru dari madrasah aliyah dan 5 (lima) guru dari madrasah tsanawiyah, yang terdiri dari 4 guru mata pelajaran Biologi, 5 guru mata pelajaran Bahasa Indonesia, dan 4 guru mata pelajaran Bahasa Arab.

Responden guru sebagian besar memiliki kualifikasi pendidikan sarjana (S1) yaitu ada 11 (sebelas orang) sedangkan 2 (dua) berpendidikan magister (S2). Jenis kelamin responden guru laki-laki sebanyak 7 (tujuh) orang dan perempuan ada 6 (enam) orang. Rata-rata masa kerja responden guru 13 tahun (masa kerja terendah 8 tahun dan tertinggi 21 tahun).

\section{Dimensi Materi Diklat}

\begin{tabular}{|c|l|l|l|l|l|l|l|c|}
\hline \multicolumn{1}{|c|}{ Dimensi Materi Diklat } & ST & \multicolumn{1}{c|}{ S } & RR & TS & STS & $\begin{array}{l}\text { Rata } \\
\text { Rata }\end{array}$ & Ket \\
\hline 1. & $\begin{array}{l}\text { Materi diklat yang disampaikan/diberikan } \\
\text { dapat mengatasi masalah pembelajaran }\end{array}$ & 4 & 5 & 4 & 0 & 0 & 4.0 & Baik \\
\hline 2. & $\begin{array}{l}\text { Materi diklat yang dibahas dapat } \\
\text { meningkatkan kualitas pembelajaran }\end{array}$ & 4 & 5 & 2 & 2 & 0 & 3.8 & Baik \\
\hline 3. & $\begin{array}{l}\text { Materi diklat yang disampaikan para } \\
\text { widyaiswara sesuai dengan kebutuhan } \\
\text { dalam pembelajaran }\end{array}$ & 3 & 6 & 0 & 4 & 0 & 3.6 & Baik \\
\hline 4. & $\begin{array}{l}\text { Materi diklat yang disampaikan } \\
\text { widyaiswara secara sistematis dan praktis }\end{array}$ & 2 & 7 & 1 & 3 & 0 & 3.6 & Baik \\
\hline 5. & $\begin{array}{l}\text { Materi diklat yang disampaikan } \\
\text { widyaiswara terkait informasi inovasi } \\
\text { pembelajaran dan Pendidikan }\end{array}$ & 6 & 3 & 3 & 1 & 0 & 4.1 & Baik \\
\hline 6. & $\begin{array}{l}\text { Materi diklat yang dikaji merupakan hal } \\
\text { baru dalam proses pembelajaran }\end{array}$ & 3 & 5 & 1 & 2 & 2 & 3.4 & Baik \\
\hline
\end{tabular}




\begin{tabular}{|l|l|l|l|l|l|l|l|l|}
\hline 7. & $\begin{array}{l}\text { Kesiapan dan ketersediaan bahan ajar } \\
\text { bagi peserta diklat selalu tepat waktu }\end{array}$ & 2 & 9 & 2 & 0 & 0 & 4.0 & Baik \\
\hline \multicolumn{8}{|c|}{ Penilaian secara umum } \\
\hline \multicolumn{8}{|c|}{} \\
\hline
\end{tabular}

Matari-materi diklat yang diberikan ke guru ditanggapi dengan baik, berdasarkan hasil uraian tabulasi angket sebesar 3.8. Meskipun begitu, ada beberapa guru yang menganggap materi diklat yang disampaikan para widyaiswara kurang sesuai dengan kebutuhan dalam pembelajaran. Ada empat (31\%) orang guru menganggap demikian. Guru beranggapan bahwa materi yang disampaikan di diklat adalah materi yang diberikan untuk siswa yang belajar pada tingkatan madrasah tsanawiyah, sementara penyelenggaraan diklat diperuntukkan guru madrasah Aliyah. Contoh pada diklat guru mata pelajaran biologi, ada materi tentang pembelajaran sel-sel pada mahluk hidup. Materi ini adalah pembelajaran siswa pada tingkat madrasah tsanawiyah. Guru beranggapan materi diklat sangat mendasar.

Ekspektasi guru terhadap kebaruan materi pembelajaran sangat besar karena dengan diklatlah salah satu media bagi guru dalam mengembangkan kompetensinya. Materi diklat guru mata pelajaran yang diikuti guru ini, kurang menampakkan kebaruan, bahkan ada guru yang beranggapan bahwa materi sama sekali bukan hal baru atau sangat tidak setuju bila disampaikan bahwa materi diklat merupakan hal yang baru dalam pembelajaran. Anggapan ini muncul karena beberapa guru yang mengikuti diklat (pada Balai Diklat Keagamaan) telah mengikuti diklat yang sama pada Kementerian Pendidikan Nasional. Materi-materi diklat telah didapatkan pada diklat-diklat sebelumnya. Sebab lain adalah begitu tingginya intensitas penelusuran informasiinformasi yang dilakukan oleh guru (juga siswa) di dunia maya (dengan internet) terkait materi-materi pembelajaran.

Mengakses materi yang berhubungan dengan pembelajaran lewat internet dewasa ini merupakan hal yang lumrah dan sudah menjadi kebiasaan didunia Pendidikan (dinamika perkembangan informasi dan teknologi), karena pengguna dengan mudahnya mencari kebutuhan akan informasi. Faktor ini cukup berpengaruh mengubah sistem dan pola pembelajaran terkait pemenuhan materi pembelajaran, dan sangat membuka peluang guru lebih banyak mengetahui informasi kebaruan akan materi dibanding widyaswara, atau siswa dibanding guru (pada satuan pendidikan). Olehnya widyaswara dituntut untuk membuat inovasi-inovasi pembelajaran pada diklat dan menyediakan informasi yang seluas-luasnya terkait materi diklat agar harapan guru dapat terpenuhi dan tujuan pelaksanaan diklat dapat tercapai dengan maksimal, efektif, dan efesien.

Materi diklat yang mendapat respon yang sangat baik oleh guru adalah materi yang terkait inovasi pembelajaran. Pada materi ini guru diberikan gambaran bagaimana menganalisis indikator mata pelajaran sesuai dengan kompetensi yang ingin dicapai dan dibutuhkan oleh siswa. Dengan proses analisis akan menggali potensi guru untuk berinovasi menemukan metode atau strategi pembelajaran yang sesuai dengan karakter belajar siswa. Inovasi pembelajaran merupakan keniscayaan pada proses belajar mengajar saat ini, agar siswa tidak merasa bosan dan mengurangi semangat belajar siswa. Kebosanan pada siswa bisa saja terjadi jika penyampaian pembelajaran berlangsung monoton tanpa variasi-variasi yang kreatif dan inovatif. Metode pembelajaran yang kreatif, inovatif, dan menyenangkan sudah banyak ditemui melalui media internet.

Materi pada diklat guru mata pelajaran Bahasa Indonesia secara umum guru menerima dengan baik, karena setidaknya memenuhi harapan guru akan penguatan materi-materi yang substantif. Materi yang bersifat substantif setidaknya menjadi oase peningkatan kompetensi dan pengembangan keprofesian guru. Materimateri yang diberikan pada diklat guru mata 
pelajaran Bahasa Indonesia, diantaranya adalah; Analisis KI-KD Indikator mata pelajaran Bahasa Indonesia, Konsep mata pelajaran Bahasa Indonesia, Pendalaman materi teks di Kelas VII, Model pembelajaran berbasis teks mata pelajaran Bahasa Indonesia MTs, Pendalaman materi teks di Kelas VIII, Pendalam materi teks di Kelas IX, dan Penilaian pembelajaran Bahasa Indonesia. Materi-materi tersebut cukup mewakili untuk peningkatan kompetensi guru.

Begitu juga dengan meteri pada Diklat Guru Mata pelajaran bahasa Arab, guru mengapresiasi dengan baik materimateri diklat. Materi-materi diklat yang diberikan banyak berhubungan dengan penguatan metode-metode pembelajaran Bahasa Arab, seperti metode mendengarkan (Istima'), metode membaca (Qira'ah), atau metode menulis (Kitabah). Penguatan metode ini akan sangat bermanfaat bagi guru dalam mengelaborasi penyampain pembelajaran ke peserta didik, dan memberikan ruang yang seluas-luasnya kepada guru dalam menerapkan metode pembelajaran sesuai dengan karakteristik peserta didik.

Secara umum materi diklat guru mata pelajaran telah tersusun berdasarkan kurikulum yang telah ditetapkan oleh Pusat Pendidikan dan Pelatihan Teknis Badan Litbang dan Diklat Kementerian Agama.
Kurikulum ini disusun berdasarkan hasil analisis kebutuhan kediklatan, sehingga meskipun masih terdapat materi yang bersifat dasar, tidak akan mengurangi substansi pokok materi-materi pembelajaran. Dan telah disesuaikan dengan karakteristik dan kompetensi guru yang akan didiklat, salah satunya guru yang mengikuti diklat telah mempunyai pengalaman belajar di kelas atau setidaktidaknya telah mengikuti micro teaching (latihan dasar mengajar bagi guru).

Penilaian peserta diklat terhadap materi dan proses penyelenggaraan diklat secara umum juga disampaikan pada evaluasi pembelajaran. Evaluasi proses pembelajaran pada pelaksanaan diklat dilakukan oleh seluruh peserta setelah seluruh materi disampaikan, yang meliputi dua aspek yaitu pengetahuan dan etika. Aspek Pengetahuan terdiri dari: Pengetahuan dan keterampilan mengajar; Penguasaan materi; Sistematika penyajian; Kemampuan menyajikan; Penggunaan metode dan alat bantu pembelajaran; dan ketercapaian tujuan. Sedangkan aspek Etika terdiri dari: Etika; Sikap terhadap peserta; Cara menjawab pertanyaan peserta; Penggunaan bahasa; Pemberian motivasi; Disiplin waktu; Kerapihan berpakaian; kerjasama (tim) (Padilah 2016).

\section{Dimensi Widyaiswara}

\begin{tabular}{|c|l|l|l|l|l|l|l|l|}
\hline \multicolumn{1}{|c|}{ Dimensi Widyaiswara } & ST & \multicolumn{1}{|c|}{ S } & RR & TS & STS & $\begin{array}{l}\text { Rata } \\
\text { Rata }\end{array}$ & Ket \\
\hline 1. & $\begin{array}{l}\text { Widyaiswara memiliki kemampuan } \\
\text { menyampaikan materi substantive mata } \\
\text { pelajaran }\end{array}$ & 3 & 6 & 4 & 0 & 0 & 3.9 & Baik \\
\hline 2. & $\begin{array}{l}\text { Widyaiswara memiliki pengalaman } \\
\text { berkenaan dengan pembelajaran }\end{array}$ & 2 & 7 & 4 & 0 & 0 & 3.8 & Baik \\
\hline 3. & Widyaiswara menguasai materi pelatihan & 4 & 5 & 4 & 0 & 0 & 4.0 & Baik \\
\hline 4. & $\begin{array}{l}\text { Widyaiswara memberikan contoh } \\
\text { pelatihan yang jelas dan mudah dipahami }\end{array}$ & 3 & 6 & 4 & 0 & 0 & 3.9 & Baik \\
\hline 5. & $\begin{array}{l}\text { Widyaiswara/instruktur menerapkan } \\
\text { berbagai metode pelatihan. }\end{array}$ & 1 & 6 & 4 & 1 & 1 & 3.4 & Baik \\
\hline
\end{tabular}




\begin{tabular}{|c|l|l|l|l|l|l|l|l|}
\hline 6. & $\begin{array}{l}\text { Widyaiswara/instruktur memberikan } \\
\text { pengarahan sebelum berdiskusi dan atau } \\
\text { seminar dengan jelas dan mudah dicerna }\end{array}$ & 3 & 7 & 3 & 0 & 0 & 4.0 & Baik \\
\hline 7. & $\begin{array}{l}\text { Widyaiswara hadir dalam kelas selalu } \\
\text { tepat waktu sesuai jadwal pembelajaran }\end{array}$ & 4 & 8 & 1 & 0 & 0 & 4.2 & Baik \\
\hline \multicolumn{6}{|c|}{ Penilaian secara umum } \\
\hline
\end{tabular}

Widyaiswara atau pemateri diklat guru mata pelajaran mendapat respon atau tanggapan yang baik (3.9) oleh guru-guru yang telah mengikuti diklat. Tanggapan ini diberikan oleh guru karena widyaiswara mampu menyampaikan materi pembelajaran dengan baik dan ketepatan waktu widyaiswara hadir dalam kelas. Penyampaian materi pembelajaran menjadi hal yang sangat penting dalam menunjang tercapainya tujuan diklat, diantaranya adalah memberikan pengetahuan dan keterampilan kepada guru agar dapat melaksanakan pengajaran yang lebih baik dan berkualitas kepada peserta didik, memotivasi guru meningkatkan kinerja dalam kegiatan belajar mengajar, dan meng-update keprofesian guru dalam memberikan pelayanan terbaik pada proses pembelajaran.

Penyampaian materi diklat kepada guru tentu harus didukung dengan metode pelatihan yang inovati dan kreatif agar tujuan pembelajaran dapat tercapai dengan sebaik-baiknya. Dengan menggunakan metode yang inovati, akan dapat menggugah gairah belajar peserta diklat ke arah yang positif, peserta terus diransang untuk mengetahui lebih banyak lagi materi pembelajaran. Dan dengan metode yang kreatif, akan memberikan suasana belajar yang menyenangkat, menggali potensi berpikir peserta diklat agar cepat mengerti dan tanggap terhadap materi pembelajaran.

Penggunaan macam-macam atau berbagai metode diklat, tidak serta merta menyenangkan semua peserta diklat. Ada juga peserta yang tidak setuju dengan beberapa metode yang diterapkan. Olehnya, metode pelatihan juga harus memperhatikan dan menyesuaikan dengan karakteristik peserta diklat. Karakteristik peserta misalnya dilihat dari rata-rata usia, pengalaman mengikuti diklat, lama atau pengalaman mengajar, atau dilihat dari daerah asal atau lingkungan peserta diklat. Peserta yang sudah sering atau pernah mengikuti diklat serupa tentu sudah familiar dengan beberapa metode diklat sehingga menganggap metode tersebut biasa-biasa saja, atau usia peserta diklat yang rata-rata tidak mudah lagi akan sedikit kesulitan dengan metode diklat yang menggunakan macam-macam teknologi pembelajaran. Tidak bisa dipungkiri masih ada guru kita yang kesulitan mengelolah pembelajaran dengan sistem komputasi (menggunakan komputer/laptop).

Kompetensi kepribadian dan sikap profesional widyaiswara sangat dijunjung tinggi, salah satunya dengan memanfaatkan waktu pembelajaran secara efektif. Memulai pembelajaran dengan tepat waktu adalah gambaran widyaiswara sangat menghargai waktu. Dengan memanfaatkan waktu secara maksimal, widyaiswara dapat menjalankan tahapan-tahapan pembelajaran sesuai perencanaan tanpa ada kesan terburu-buru (dikejar oleh waktu), menyampaikan materi secara utuh, dan menyediakan waktu yang cukup bagi peserta diklat berinteraksi dengan widyaiswara untuk memahami materi pembelajaran lebih dalam dan maksimal.

Kompetensi widyaiswara merupakan persyaratan mutlak yang harus dipertimbangkan dalam pelaksanaan diklat. Widyaiswara harus memiliki pengetahuan dan keterampilan terhadap mata diklat yang diajarkan, mampu menyusun bahan ajar yang inovatif, mampu mengangkat motivasi belajar peserta diklat, berprilaku baik, dan membangun komunikasi yang baik di lingkungan diklat. Dalam Peraturan Kepala Lembaga Administrasi Negara Nomor 5 Tahun 2008 tentang Standar Kompetensi Widyaiswara disebutkan bahwa Standar kompetensi Widyaiswara adalah 
kemampuan minimal yang secara umum dimiliki oleh Widyaiswara dalam melaksanakan tugas, tanggungjawab dan wewenangnya untuk mendidik, mengajar, dan/atau melatih PNS, yang terdiri atas kompetensi pengelolaan pembelajaran, kompetensi kepribadian, kompetensi sosial, dan kompetensi substantif.

Widyaiswara yang memiliki kompetensi sesuai dengan standar yang ditetapkan akan memberikan manfaat pada efektivitas kerja. Efektivitas akan membuat tujuan pelaksanan dapat dicapai secara maksimal. Pengertian efektivitas menurut Siagian (2012: 151) adalah sebagai berikut Efektivitas kerja berarti penyelesaian pekerjaan tepat pada waktu yang ditetapkan. Artinya apakah pelaksanaan suatu tugas dinilai baik atau tidak sangat tergantung pada bilamana tugas itu diselesaikan, dan tidak terutama menjawab pertanyaan bagaimana cara melaksanakannya dan berapa biaya yangdikeluarkan untuk itu. Sejalan dengan definisi di atas, Siagian (2012: 153) menyatakan bahwa untuk mengukur efektivitas terdapat beberapa prinsip, yaitu sebagai berikut : 1. Ukuran waktu 2. Ukuran harga 3. Ukuran nilai 4. Ukuran ketelitian (Yulian and Akbar, 2016:3).

Kirkpatrick (2006,

menyebutkan dalam penilaian/pengukuran efektivitas pendidikan dan pelatihan terdapat empat tingkatan yaitu: a. Reaksi (Reaction)/Tanggapan b. Pembelajaran (Learning) c. Perilaku d. Hasil (Result). (Handayani, Suryono, and Said, n.d:827). Dengan adanya efektifitas kerja maka akan berdampak pada keseluaruah pembelajaran. Pembelajaran efektif sangat menguntungkan penyelenggaraan diklat. Pembelajaran efektif adalah pembelajaran dimana peserta diklat memperoleh keterampilan-keterampilan yang spesifik, pengetahuan dan sikap serta merupakan pembelajaran yang disenangi peserta diklat. Intinya bahwa pembelajaran dikatakan efektif apabila terjadi perubahan-perubahan pada aspek kognitif, afektif, dan psikomotor (Reiser Robert, 1996). (Rosyidi, 2017:104)

\section{Dimensi Metode Pelaksanaan Diklat}

\begin{tabular}{|r|l|l|l|l|l|l|l|c|}
\hline & \multicolumn{1}{|c|}{ Dimensi Metode Diklat } & ST & \multicolumn{1}{c|}{ S } & RR & TS & STS & $\begin{array}{l}\text { Rata } \\
\text { Rata }\end{array}$ & Ket \\
\hline 1. & $\begin{array}{l}\text { Metode pembelajaran/penyajian } \\
\text { ditetapkan dalam pembelajaran diklat }\end{array}$ & 2 & 8 & 3 & 0 & 0 & 3.9 & Baik \\
\hline 2. & $\begin{array}{l}\text { Metode yang digunakan sangat sesuai } \\
\text { dengan tema atau materi pelatihan }\end{array}$ & 4 & 5 & 3 & 1 & 0 & 3.9 & Baik \\
\hline 3. & $\begin{array}{l}\text { Widyaiswara/instruktur menggunakan } \\
\text { berbagai metode pembelajaran }\end{array}$ & 1 & 7 & 3 & 2 & 0 & 3.5 & Baik \\
\hline 4. & $\begin{array}{l}\text { Widyaiswara mengunakan peraga dalam } \\
\text { peroses pembelajaran }\end{array}$ & 3 & 7 & 2 & 1 & 0 & 3.9 & Baik \\
\hline 5. & $\begin{array}{l}\text { Widyaiswara/instruktur menggunakan } \\
\text { media pembelajaran dengan optimal }\end{array}$ & 3 & 6 & 3 & 1 & 0 & 3.8 & Baik \\
\hline 6. & $\begin{array}{l}\text { Mata pelajaran ditetapkan secara rinci } \\
\text { dalam jadwal pembelajaran }\end{array}$ & 2 & 9 & 2 & 0 & 0 & 4.0 & Baik \\
\hline 7. & $\begin{array}{l}\text { Widyaiswara/instruktur menyusun Silabus } \\
\text { pembelajaran }\end{array}$ & 2 & 5 & 5 & 1 & 0 & 3.6 & Baik \\
\hline 8. & $\begin{array}{l}\text { Widyaiswara/instruktur menyusun } \\
\text { Rencana Pelaksanaan Pembelajaran (RPP) }\end{array}$ & 1 & 5 & 7 & 0 & 0 & 3.5 & Baik \\
\hline 9. & $\begin{array}{l}\text { Widyaiswara membuka ruang/diskusi } \\
\text { yang memadai }\end{array}$ & 2 & 9 & 2 & 0 & 0 & 4.0 & Baik \\
\hline
\end{tabular}




\begin{tabular}{|c|l|l|l|l|l|l|l|l|}
\hline 10. & $\begin{array}{l}\text { Alokasi waktu pembelajaran digunakan } \\
\text { secara efektif dan efisien }\end{array}$ & 3 & 9 & 1 & 0 & 0 & 4.2 & Baik \\
\hline 11. & $\begin{array}{l}\text { Pembelajaran bersifat interaktif dan tidak } \\
\text { monoton }\end{array}$ & 3 & 7 & 3 & 0 & 0 & 4.0 & Baik \\
\hline 12. & $\begin{array}{l}\text { Widyaiswara memberikan motivasi kerja } \\
\text { kepada para peserta diklat }\end{array}$ & 4 & 8 & 0 & 1 & 0 & 4.2 & Baik \\
\hline 13. & $\begin{array}{l}\text { Pemberian tugas oleh } \\
\text { widyaiswara/instruktur selalu tuntas }\end{array}$ & 2 & 8 & 2 & 1 & 0 & 3.8 & Baik \\
\hline 14. & $\begin{array}{l}\text { Iklim kelas/pembelajaran sangat kondusif } \\
\text { dan komunikatif antara peserta diklat } \\
\text { dengan widyaiswara/instruktur }\end{array}$ & 3 & 8 & 2 & 0 & 0 & 4.1 & Baik \\
\hline \multicolumn{6}{|c|}{ Penilaian secara umum } \\
\hline
\end{tabular}

Metode adalah salah satu komponen kediklatan yang berperan penting dalam mencapai tujuan pelaksanaan diklat. Metode yang baik, konsruktif, dan bertepat guna akan memudahkan peserta diklat menerima materi dan memberikan rasa nyaman peserta diklat mengikuti rangkaian proses kediklatan. Metode diklat guru mata pelajaran mendapat respon yang baik (3.9) dari guru-guru yang telah mengikuti diklat. Guru mengapresiasi dengan baik alokasi waktu pembelajaran yang dapat digunakan secara efektif dan efesien, karena dengan waktu yang cukup guru dapat berinteraksi dengan widyaiswara secara maksimal memperdalam materi pembelajaran. Guru juga mengapresiasi kemampuan widyaiswara memberikan motivasi kerja kepada peserta didik. Motivasi dalam bekerja sangat dibutuhkan oleh guru dalam membangun kepercayaan melaksanakan tugas dan tanggungjawab sebagai aparatur sipil negara yang berdampak pada peningkatan kinerja. Kinerja yang baik dan maksimal tentu menjadi harapan semua guru dalam memberikan pelayanan pembelajaran.

Selain ketersediaan waktu, penerapan metode pembelajaran yang tepat juga memberikan peluang kepada peserta diklat untuk berinteraksi dengan widyaiswara. Salah satu metode yang digunakan pada diklat substantif guru mata pelajaran adalah metode partisipatif learning. Peserta diklat digiring untuk berpartisipati aktif dalam pembelajaran, widyaiswara berusaha menggali informasi-informasi dan kebutuhan-kebutuhan substansi materi yang diinginkan peserta diklat. Dan selanjutnya widyaiswara memberikan solusi-solusi dan melaksanakan evaluasi atau penilaian terhadap jalannya proses pembelajaran.

Metode brainstorming (curah pendapat) juga salah satu metode yang digunakan oleh widyaiswara dalam pelaksanaan diklat. Widyaiswara mengangkat suatu masalah (yang berhubungan dengan guru dan kediklatan) kemudian meminta pendapat para peserta diklat mencari solusi atau pemecahan masalah. Metode ini sangat berguna dalam meransang daya piki guru, dan membuat hidup jalannya pembelajaran.

Meskipun secara umum metode kediklatan mendapat respon yang baik oleh guru (peserta diklat), guru masih menaruh harapan yang tinggi terhadap beberapa indikator metode diklat agar mendapat substansi materi secara aktual. Diantaranya adalah penyusunan rencana pembelajaran (RPP) yang sebagian besar guru masih meragukan kompetensi widyaiswara. Penyusunan RPP oleh widyaswara masih dianggap biasa-biasa saja oleh guru. Hal ini dimaklumi karena memang guru lebih memiliki pengalaman menyusun RPP dibanding widyaiswara. Penyusunan RPP merupakan kewajiban yang harus dipenuhi oleh guru setiap awal semester pembelajaran, sedangkan widyaiswara hanya mengikuti pedoman kurikulum dari pusat dan juga diperoleh melalui selflearning yang dilakukan oleh 
widyaswara dalam menunjang peningkatan kompetensinya.

Penyelenggara diklat termasuk widyaiswara diharapkan mampu meramu dan berinovasi menciptakan metode pelatihan. Sistem atau metode penyampaian baru yang bisa dilakukan dengan metode studi lapangan, diskusi, seminar konferensi, role playing, simulasi, studi kasus, dan sebagainya (Nuraeni and Riyanto, 2017:24)

Salah satu metode pelatihan yang digunakan pada diklat adalah pembelajaran secara kolaboratif. Cymer (dalam Sulaeman, 2017) keuntungan menggunakan pembelajaran kolaboratif bagi pebelajar adalah terjadinya diskusi sebaya yang berfungsi dalam menggabungkan pengalaman dan pengetahuan yang dimiliki sebagai cara membentuk koginiftif peserta, lebih lanjut disebutkan keuntungan bekerja secara kolaboratif adalah peserta akan lebih memahami penyampaian suatu masalah atau pengatahuan dari temannya yang satu profesi daripada fasilitatornya (Sulaeman, 2017:35).

Dalam diklat, pembelajaran lebih ditekankan pada keaktifan peserta diklat yang didasarkan pada pengalaman selama menjalankan profesinya. Hal ini lebih memberikan manfaat kepada kepercayaan diri peserta dalam mengatasi permasalahan yang nantinya akan dihadapi. Pernyataan tersebut sesuai dengan Zakarija (2005) menyatakan pendekatan pelatihan yang berpusat pada peserta ini dapat menunjukkan manfaatnya yang nyata dalam proses pembelajaran. Pendekatan ini berangkat dari asumsi bahwa pesertalah yang lebih tahu dan memahami permasalahan mereka, seorang trainer hanya membantu dalam proses belajarnya. Dalam pendekatan ini, seorang trainer menyediakan lingkungan yang mendukung bagi peserta untuk mengeksplorasi, berjuang, dan menjelajahi pikirannya, sehingga mereka memperoleh insight yang nyata, sesuai dengan masalah mereka (Widianto, 2018:46).

Ada beberapa metode diklat yang dapat dikembangkan. Menurut Cherrington dalam Hasan Basri (2015), dikatakan bahwa metode dalam pendidikan pelatihan secara garis besar dibagi menjadi 2 yaitu on the job training dan off the job training. On the job training lebih banyak digunakan dibandingkan dengan off the job training. Hal ini disebabkan karena metode on the job training lebih berfokus pada peningkatan produktivitas secara cepat, sedangkan metode off the job training lebih cenderung berfokus pada perkembangan dan pendidikan jangka panjang. Metode On the job training, antara lain: Job instruclion training, Apprenticeship, Job rotation dan transfer, Couching dan counseling; sementara Off the Job Training terdiri dari: Vestibule training, Lecture, Independent self-study, Visual presentations, Conferences dan discussion, Case studies, Role playing, Simulation, Programmed instruction, Computer-based training, Laboratory training. (Siregar, 2018:163)

Sebagai suatu proses, istilah manajemen pendidikan dan pelatihan berkaitan dengan siklus yang menurut Notoatmodjo (2009, h. 18) secara garis besar adalah sebagai berikut: a. Analisis Kebutuhan Pelatihan (Training Need Assesment), yang bertujuan untuk mencari atau mengidentifikasi kemampuankemampuan yang diperlukan oleh karyawan dalam rangka menunjang kebutuhan organisasi. b. Menetapkan Tujuan Pelatihan, berupa perumusan kemampuan yang diharapkan dari pelatihan tersebut yaitu adanya perubahan kemampuan. c. Pengembangan Kurikulum, yaitu menentukan metoda belajar mengajar yang akan digunakan, serta alat bantu belajar mengajar yang diperlukan dalam pelatihan tersebut. d. Persiapan Pelaksanaan Diklat. Sebelum pendidikan dan pelatihan dilaksanakan, terlebih dahulu dilakukan persiapan yang pada umumnya mencakup kegiatan-kegiatan administrasi. e. Pelaksanaan Diklat, d. Evaluasi, yang mencakup (1) Evaluasi terhadap proses kegiatan Diklat, dan (2) evaluasi terhadap hasil dari kegiatan diklat. (Siregar, 2018:156) 
PNS yang telah dilatih di diklat diharapkan dapat memenuhi kualifikasi kompetensi seperti ditegaskan oleh Prayitno dalam (Rahman 2012) menyatakan bahwa standar kompetensi mencakup 3 hal, yaitu: (1) Ketrampilan, yaitu kemampuan untuk menunjukkan tugas pada tingkat kriteria yang dapat diterima secara terus menerus dengan kegiatan yang paling sedikit;

Pengetahuan, yakni fakta dan angka dibalik aspek teknis; (3) Sikap, yaitu kesan yang ditunjukkan kepada pelanggan dan orang lain bahwa yang bersangkutan mampu berada dalam lingkungan kerja (Nurhajati and Bachri, 2017:164)

\section{PENUTUP}

Penyampaian materi diklat, penggunaan metode kediklatan, dan kompetensi widyaiswara, secara umum mendapat respon yang baik oleh guru. Melalui dukungan maksimal ketiga komponen tersebut, guru mendapat pengalaman belajar yang konstruktif dan pengembangan wawasan cakrawala pengetahuan, penguatan sikap serta keterampilan terhadap penguasaan mata pelajaran yang diampuh.

Secara umum pelaksanaan diklat direspon secara baik oleh guru, karena dengan diklat, akan memberikan pengetahuan dan keterampilan kepada guru sehingga dapat menyediakan pelayanan yang lebih baik dan berkualitas kepada peserta didik, dapat memotivasi guru dalam meningkatkan kinerja dalam pembelajaran, dapat meningkatkan kompetensi dasar sebagai guru (pelaksanaan tupoksi secara maksimal), serta dapat meningkatkan kemapuan guru dalam meningkatkan kompetensinya.

Secara umum guru memberikan tanggapan yang baik terhadap proses penyelenggaraan diklat, baik pada materi, widyaiswara, maupun pada metode pelaksanaan diklat. Guru berharap penyelenggaraan diklat memperhatikan efesiensi dan efektivitas, membuat materi yang esensial sesuai dengan tugas dan tanggungjawab guru mata pelajaran. Inovasi-inovasi metode pembelajaran harus terus dikembangkan dalam rangka memberikan pelayanan pembelajaran yang maksimal. Tanggapan guru terhadap penyelenggaraan diklat juga dilihat dari evaluasi penyelenggara secara langsung, hasil evaluasi tersebut memberikan gambaran proses penyelenggaraan diklat berjalan secara baik.

Widyaiswara salah aspek penting berhasil tidaknya proses penyelenggaraan diklat, olehnya kompetensi widyaiswara juga harus mendapat perhatian dari pemerintah. Training of trainer lebih digiatkan lagi dalam rangkat memberikan pengayaan dan peningkatan keterampilan widyaiswara. Pelatihan widyaiswara harus merata dan menyentuh semua widyaiswara agar tidak yang ketinggalan informasi terhadap substansi diklat maupun perkembangan ilmu pengetahuan dan teknologi.

\section{UCAPAN TERIMAKASIH}

Terselesainya tulisan ini tentu tidak dengan usaha sendiri dari penulis, banyak pihak telah membantu dan berkonstribusi dalam tulisan ini. olehnya penulis menghaturkan banyak terimakasih kepada Bapak Kepala Balai Litbang Agama Makassar atas yang telah memberi kesempatan untuk melaksanakan penelitian. Hatur terimakasih juga penulis sampaikan kepada rekan-rekan peneliti atas kesediaan waktu untuk berdiskusi dan memberikan masukan terkait substansi penelitian. Dan penghargaan yang setinggi juga

\section{DAFTAR PUSTAKA}

Anwar, Muhammad. n.d. "PENERAPAN PENDIDIKAN DAN PELATIHAN BERBASISKAN EMOTIONAL SPIRITUAL QUOTIENT (ESQ) PADA BALAI DIKLAT KEAGAMAAN MANADO." 
Handayani, Wahyu Tri, Agus Suryono, and Abdullah Said. n.d. "EFEKTIVITAS PELAKSANAAN PENDIDIKAN DAN KEPEMIMPINAN PEGAWAI NEGERI SIPIL (Studi Di Badan Kepegawaian Daerah Kabupaten Probolinggo)." Jurnal Administrasi Publik (JAP) 3 (5): 824-28.

Hidayati, Nurul, and Muhammad Khafid. 2015. "PENGARUH MOTIVASI KERJA, KOMPENSASI, DAN PENGALAMAN DIKLAT TERHADAP KINERJA GURU EKONOMI/AKUNTANSI DI SMA NEGERI SE-KABUPATEN TEGAL." Economic Education Analysis Journal 4 (1): 211-18.

Nuraeni, Lenny, and Arifah A Riyanto. 2017. "EFEKTIVITAS DIKLAT BERJENJANG TINGKAT DASAR TERHADAP PENINGKATAN KOMPETENSI PEDAGOGIK PENDIDIK PAUD." Jurnal Ilmiah P2M STKIP Siliwangi 5 (1): 21-33.

Nurhajati, Widi Asih, and Bachtiar Sjaiful Bachri. 2017. "PENGEMBANGAN KURIKULUM PENDIDIKAN DAN PELATIHAN ( DIKLAT ) BERBASIS KOMPETENSI DALAM MEMBANGUN PROFESIONALISME PEGAWAI NEGERI SIPIL ( PNS )" 2 (2): 15664.

Nurmasari. 2016. "Pelaksanaan Pendidikan Dan Pelatihan Pegawai Pada Kantor Badan Kepegawaian Daerah Di Kabupaten Bengkalis." Jurnal Publika 2 (1): 1-15.

Padilah, Ipah Parihah. 2016. "MANAJEMEN PENDIDIKAN DAN PELATIHAN TEKNIS FUNGSIONAL PENINGKATAN KOMPETENSI GURU DI BALAI DIKLAT KEAGAMAAN." Jurnal Isema, Islamic Education Management 1 (1): 55-66.

Rahayu, Setyani Budi. 2016. "PENGEMBANGAN MODEL DIKLAT GURU SOSIOLOGI SMA
TENTANG

STRATEGI

PEMBELAJARAN DISCOVERY-

INQUIRY BERBANTUAN CD

INTERAKTIF." Jurnal Kelola 3 (1): 131-47.

Rosyidi, Agus Mukhtar. 2017. "MODEL DAN STRATEGI PEMBELAJARAN DIKLAT (Kajian Alternatif Yang Efektif)." Jurnal Andragogi V (1): 100-111.

Siregar, Edison. 2018. "FAKTORFAKTOR YANG MEMPENGARUHI MANAJEMEN PENDIDIKAN DAN PELATIHAN (DIKLAT) DALAM UPAYA PENGEMBANGAN SUMBER DAYA MANUSIA (SDM)." Jurnal JDP 11 (2): 153-66.

Sugiarto, Kristono, Dewiyani Sunarto, and Yoppy Mirza Maulana. 2016. "RANCANG BANGUN SISTEM INFORMASI ANALISIS KEBUTUHAN DIKLAT BAGI GURU SMK DI DISPENDIK PROVINSI JAWA TIMUR.” Jurnal JSIKA 5 (2): 1-10.

Sulaeman, Asep Agus. 2017. "Desain Program Diklat Keterampilan Proses Sains Untuk Guru IPA SMP Dalam Mewujudkan Pembelajaran Dengan Pendekatan Saintifik." Jurnal Penelitian Pendidikan IPA 2 (1): 30 37.

Sulistyo, Bambang, Maria Magdalena Minarsih, and M Mukeri Warso. 2016. "PENGARUH PENDIDIKAN DAN LATIHAN PROFESI GURU (PLPG), KEDISIPLINAN GURU , DAN KOMPETENSI GURU TERHADAP KINERJA GURU DI SMP MASEHI JEPARA.” Journal Of Management 2 (2): n.p.

Syaifulloh, Muhammad, and Budi Adjar Pranoto. 2017. "ANALISIS PROFESIONALISME GURU, DIKLAT DAN PRESTASI GURU TERHADAP KUALITAS PENDIDIKAN PADA SEKBIN 3 UPTD PENDIDIKAN KECAMATAN BREBES 
KABUPATEN BREBES.” Jurnal JPSD 3 (1): 17-25.

Wardoyo, Sidik, and Ki Supriyoko. 2018. "Pengaruh Pendidikan Dan Latihan, Motivasi Kerja Dan Masa Kerja Terhadap Profesionalisme Guru SMKN Di Wonosobo.” Jurnal Media Manajemen Pendidikan 1 (1): 10715.

Widianto, Edi. 2018. "Pola Penyelenggaraan Pendidikan Dan Pelatihan Di Balai Diklat Keuangan Kota Malang." Jurnal Kajian Teori Dan Praktik Kependidikan 3 (1): 4049.

Yulian, Faisal Adam, and Gugun Geusan Akbar. 2016. "PENGARUH PERENCANAAN PENDIDIKAN DAN PELATIHAN TERHADAP EFEKTIVITAS PELAKSANAAN PENDIDIKAN DAN PELATIHAN DI UNIT PELAKSANAAN TEKNIS DAERAH (UPTD)-BALAI LATIHAN KERJA (BLK) DINAS SOSIAL TENAGA KERJA DAN TRANSMIGRASI KABUPATEN GARUT.” Jurnal Pembangunan Dan Kebijakan Publik 07 (01): 1-9.

Peraturan Menteri Agama Republik Indonesia Nomor 75 Tahun 2015. Penyelenggaraan Pendidikan dan Pelatihan Pegawai Kementerian Agama. Kementerian Agama Republik Indonesia.

Peraturan Menteri Agama Republik Indonesia Nomor 43 tahun 2016. Sistem Informasi Manajemen Pendidikan dan Pelatihan pada Kementerian Agama. Kementerian Agama Republik Indonesia.

Peraturan Kepala Lembaga Administrasi Negara Nomor 5 Tahun 2008 tentang Standar kompetensi widyaiswara. 